\title{
Pengaruh Pembelajaran Jarak Jauh Bermuatan STEAM Terhadap Karakter Kreatif dan Kemandirian
}

\author{
Dina Amalia $^{1 凶}$, Joko Sutarto', Yuli Kurniawati Sugiyo Pranoto ${ }^{1}$ \\ Pendidikan Anak Usia Dini, Universitas Negeri Semarang, Indonesia(1) \\ DOI: $\underline{10.31004 / \text { obsesi.v6i3.1765 }}$
}

\begin{abstract}
Abstrak
Pandemi covid-19 berdampak pada bidang pendidikan. Pendidikan yang semula dengan metode tatap muka, kini diubah menjadi pembelajaran jarak jauh. Pembelajaran yang sesuai saat pembelajaran jarak jauh yaitu pembelajaran bermuatan STEAM. Karena muatan STEAM merupakan isu penting dalam pendidikan saat ini, sehingga karakter kreatif dan kemandirian anak dapat diintegrasikan melalui pembelajaran bermuatan STEAM. Tujuan penelitian ini untuk mengetahui pengaruh pembelajaran jarak jauh bermuatan STEAM terhadap karakter kreatif dan kemandirian anak dibeberapa PAUD di Jawa Tengah. Penelitian ini merupakan penelitian deskriptif kuantitatif dengan pendekatan survei. Hasil penelitian ini yaitu pembelajaran jarak jauh bermuatan STEAM yang merupakan keterbaruan dari hasil integrasi STEM dengan tambahan Art dapat berpengaruh terhadap karakter kreatif dan kemandirian. Berdasarkan pernyataan permasalahan penelitian, dirumuskan pertanyaan bagaimana pengaruh pembelajaran jarak jauh bermuatan STEAM terhadap karakter kreatif dan kemandirian anak. Dampak dari penelitian pembelajaran jarak jauh bermuatan STEAM berupa pengembangan sikap kreatif dan kemandirian yang dapat diaplikasikan dalam kegiatan sehari-hari.
\end{abstract}

Kata Kunci: STEAM; karakter kreatif; kemandirian

\begin{abstract}
Covid-19 pandemic has had an impact on the education sector. Education which was originally a face to face method has now been changed to distance learning. The appropriate learning during distance learning is STEAM content learning. Because STEAM content is an important issue in education today so that the creative character and independence of children can be integrated through STEAM learning. The purpose of this study was to determine the effect of distance learning containing STEAM on the creative character and independence of children in several PAUD in Central Java. This research is a quantitative descriptive study with a survey approach. The results of this study are distance learning containing STEAM which is the renewal of the results of STEAM integration with additional Art that can affect creative and independent characters. Based on the research problem statement, the question is formulated how the influence of distance learning with STEAM on the creative character and independence of children. The impact of distance learning research containing STEAM is the development of creative attitudes and independence that can be applied in daily activities.
\end{abstract}

Keywords: STEAM; creative character; independence

Copyright (c) 2021 Dina Amalia, Joko Sutarto, Yuli Kurniawati Sugiyo Pranoto

$\triangle$ Corresponding author :

Email Address : dinamalia11@gmail.com (Kudus, Jawa Tengah, Indonesia)

Received 22 May 2021, Accepted 26 August 2021, Published 28 August 2021

Jurnal Obsesi : Jurnal Pendidikan Anak Usia Dini, 6(3), 2022 | 1233 


\section{PENDAHULUAN}

Berdasarkan surat edaran menteri pendidikan dan kebudayaan (Mendikbud) nomor 4 tahun 2020 yang diterbitkan pada tanggal 24 maret 2020 perihal pelaksanaan kebijakan pendidikan dalam masa darurat penyebaran corona virus disease (COVID-19), yang salah satu isinya adalah belajar dari rumah dengan kegiatan pembelajaran secara daring atau jarak jauh. Selama pandemi berlangsung, kini pembelajaran daring telah dilakukan hampir di penjuru dunia (Goldschmidt, 2020). Maka selama pandemi covid-19 berlangsung setiap sekolah melaksanakan kegiatan pendidikan dengan pembelajaran jarak jauh.

Pandemi covid-19 adalah krisis kesehatan yang melanda hampir di seluruh penjuru dunia (Purwanto, 2020). Pandemi ini berdampak pada berbagai bidang, salah satunya di pendidikan. Banyak negara memutuskan untuk sementara menutup sekolah, dan kampus selama masa pandemi covid-19 berlangsung. Setiap negara membuat kebijakan-kebijakan untuk mengatasi permasalahan yang sedang terjadi. Untuk mengatasi wabah pandemi covid -19 , semua negara menerapkan sebuah tindakan salah satunya dengan melakukan gerakan social distancing yaitu jarak sosial yang dirancang untuk mengurangi interaksi orang-orang dalam komunitas yang lebih luas (Wilder-Smith \& Freedman, 2020). Dengan adanya social distancing maka pembelajaran di sekolah menjadi terhambat dan tidak bisa dilakukan secara langsung. Hal ini juga berpengaruh pada pelaksanaan kegiatan pendidikan.

Pendidikan yang semula dengan metode tatap muka di lembaga pendidikan, kini diubah menjadi pembelajaran daring/online dan dilaksanakan dari rumah masing-masing untuk mencegah dan menanggulangi penyebaran virus covid-19 ini. Kebijakan tersebut berlaku bagi semua jenjang pendidikan baik dari tingkat PAUD hingga tingkat perguruan tinggi. Hal ini merupakan langkah inisiatif dari pemerintah karena pembelajaran tidak harus bertemu langsung, tidak harus bertatap muka langsung, namun dilaksanakan dengan sosial media, media teknologi, dan aplikasi. Pembelajaran tersebut dikenal dengan pembelajaran daring (Adiwijaya, 2020).

Pembelajaran yang sesuai saat pembelajaran jarak jauh yaitu dengan menggunakan pembelajaran bermuatan STEAM. (Gunawan et al., 2020) mengatakan STEAM merupakan muatan pembelajaran kolaboratif yang mengarah pada pemberian motivasi, inovasi yang dapat melahirkan insan kreatif menuju masyarakat berprestasi yang tidak hanya memperkuat pembelajaran dalam disiplin ilmu. STEAM digunakan untuk fokus pada pemahaman tentang sifat terintegrasi dari disiplin sains, teknologi, teknik, seni, dan matematika, serta jangka panjang dalam keberhasilan akademik, dan kesejahteraan ekonomi anak-anak (Herro \& Quigley, 2016). Muatan pembelajaran STEAM memiliki dampak terhadap anak usia dini salah satunya yaitu meningkatkan minat anak dan pemahaman dalam teknologi dan kemampuan untuk memecahkan masalah di dunia nyata (Thuneberg et al., 2018). Seperti yang dijelaskan oleh (Hong, 2018) bahwa STEAM merupakan kebijakan pendidkan sebagai rencana dasar untuk membina dan mendukung sumber daya manusia dibidang ilmu dan teknolog. Karena, generasi penerus bangsa yang berkualitas dapat terbentuk jika sumber daya yang menjalankan penddkan menguasai teknologi sesuai perkembangan zaman (Sutarto et al., 2021).

STEAM berkembang dari STEM dengan penambahan unsur "Art" didalamnya. Unsur seni atau "Art" berkontribusi terhadap: 1) kemampuan berpikir yang meliputi kegiatan menalar, intuisi, persepsi, imajinasi, kreativitas, problem solving; 2) kemampuan sosial yang meliputi kepercayaan diri, pengendalian diri, resolusi konflik, kolaborasi, empati dan toleransi; 3) motivasi untuk belajar dengan indikasi keterlibatan aktif, perhatian lebih, persisten dan berani mengambil resiko, hal ini tentu saja menjadikan STEAM sebagai salah satu pendekatan terkini yang dapat diterapkan dalam Pendidikan Anak Usia Dini (Putri \& Taqiudin, 2021).

Pembelajaran berbasis STEAM (Science, Technology, Engineering, Art, and Mathematics) dapat membantu siswa untuk merangsang kamampuan proses berpikir dalam menghadapi tantangan di era globalisasi (D Henriksen, 2017). Pembelajaran STEAM kini 
DOI: 10.31004/obsesi.v6i3.1765

menjadi perhatian dunia pendidikan (Kang, 2019). Sehingga penerapan STEAM di kelas dapat menghasilkan produk pembelajaran yang kompleks dan sempurna dalam meningkatkan kualitas pendidikan (Danah Henriksen, 2014) . Dalam proses pembelajaran STEAM guru memiliki banyak tugas seperti mengamati, memberi stimulus dengan memberikan pertanyaan, memberikan pendapat dan saran, serta mengevaluasi hasil karya anak. Sementara itu anak secara bersama-sama dalam suatu kelompok belajar membangun pemahaman tentang konsep belajar yang terintegrasi dalam STEAM (Yakman \& Lee, 2012).

Menambahkan uraian diatas, pembelajaran bermuatan STEAM dapat mendorong anak untuk mengembangkan rasa ingin tahu, keterbukaan, dan pengalaman (Perignat \& KatzBuonincontro, 2019) serta mengajukan pertanyaan sehingga anak membangun pengetahuan disekitarnya dengan mengeksplorasi, mengamati, menemukan, dan menyelidiki sesuatu yang ada disekitarnya (Limbong et al., 2019).

Selain itu muatan STEAM digunakan berdasarkan kelebihannya yaitu muatan pembelajaran yang telah terintegrasi dengan baik memiliki peluang untuk membuat program melalui wacana sosial untuk mengintegrasikan teori pembelajaran yang saling melengkapi seperti yang diinginkan (Kelley \& Knowles, 2016). Pernyataan tersebut dapat diartikan bahwa muatan STEAM yang terintergrasi dengan baik memiliki kesempatan untuk menciptakan program melalui sosial untuk memadukan teori-teori pelengkap. Sekolah diminta untuk mengintegrasikan pembelajaran bermuatan STEAM dengan baik dan mengembangakan kemampuan pedagogi sehingga sekolah dapat sepenuhnya memanfaatkan potensi STEAM kepada anak (Margot \& Kettler, 2019).

Menambahkan uraian diatas, saat pembelajaran jarak jauh anak masih dapat menanamkan karakter kreatif dan kemandirian. Menurut (Becker \& Park, 2011) bahwa karakter kreatif dan kemandirian dapat diintegrasikan melalui pembelajaran bermuatan STEAM, karena muatan STEAM merupakan isu penting dalam pendidikan saat ini. Muatan STEAM merupakan integrasi dari pembelajaran sains, teknologi, teknik, seni, dan matematika yang disarankan untuk membantu kesuksesan keterampilan abad ke-21, karena pendidkan abad 21 harus berorientasi pada ilmu pengetahuan dan sains alam disertai dengan sains sosial dan kemanusiaan yang dapat membangun sikap keilmuan yaitu kritis, logis, analitis, kreatif, dan mampu beradaptasi, sehingga pada jenjang pendidikan perlu ditanamkan jiwa kemandirian (Mulyani, 2019). Muatan STEAM dapat berkembang apabila dikaitkan dengan lingkungan, sehingga terwujud sebuah pembelajaran yang menghadirkan dunia nyata yang dialami anak dalam kehidupan sehari-hari (Subramaniam et al., 2012). Hal ini berarti melalui muatan STEAM anak tidak hanya sekedar menghafal konsep saja, tetapi lebih kepada bagaimana anak mengerti serta memahami konsep-konsep sains dan kaitanya dalam kehidupan sehari-hari.

Berdasarkan uraian diatas, dapat disimpulkan bahwa muatan STEAM merupakan akronim dari sains, teknologi, teknik, seni, dan matematika. Muatan pembelajaran lima ilmu ini, STEAM memiliki dampak terhadap anak usia dini salah satunya yaitu meningkatkan karakter kreatif dan kemandirian anak, dengan menerapkan pembelajaran bermuatan STEAM anak mengerti dan memahami konsep-konsep sains dan kaitanya, serta anak dapat menanamkan kebiasaan bersikap kreatif dan mandiri dalam kehidupan sehingga anak memiliki kesadaran dan komitmen untuk menerapkan dalam kehidupan sehari-hari.

Dalam penulisan artikel ini peneliti menggali informasi dari penelitian-penelitian sebelumnya sebagai bahan perbandingan, baik mengenai kekurangan atau kelebihan yang sudah ada. Selain itu, peneliti juga menggali informasi dari buku maupun jurnal dalam rangka mendapatkan suatu informasi yang ada sebelumnya tentang teori yang berkaitan dengan judul yang digunakan untuk memperoleh landasan teori ilmiah. Berikut penelitian-penelitian terdahulu : 1) Penelitian Putri, S. U., \& Taqiudin, A. A. tahun 2021 dengan judul Steam-PBL: Strategi Pengembangan Kemampuan Memecahkan Masalah Anak Usia Dini. Penelitian ini menggunakan mixed method concurrent embedded design. Partisipan yang terlibat adalah 14 anak usia 5-6 tahun di salah satu TK di Kabupaten Purwakarta. Hasil penelitian menunjukkan bahwa pembelajaran STEAMPBL di PAUD dilakukan melalui tahapan reflection, research, 
discovery, application dan communication. Sementara itu, kemampuan memecahkan masalah anak mengalami perkembangan yang semula pada umumnya berada pada kriteria "Belum berkembang" dan "Mulai Berkembang" meningkat menjadi "Berkembang Sesuai Harapan" dan "Berkembang Sangat Baik"; 2) Penelitian Irmayani Limbong, Muniroh Munawar, dan Nila Kusumaningtyas, tahun 2019 dengan judul Perencanaan Pembelajaran PAUD Berbasis STEAM. Penelitian ini menggunakan metode penelitian kualitatif. Teknik pengumpulan data yang digunakan berupa wawancara, observasi lapangan dan reflektif jurnal. Perencanaan menjadi bagian terpenting dalam sebuah proses pembelajaran, yang lebih menitikberatkan pada 4C (Communication, Collaborative, Creatical Thingking, and Creativity). Pembelajaran berbasis STEAM (Science, Technology, Eingeneering, Art and Mathematic) ini akan membantu melatih anak untuk mampu menganalisa permasalahan-permasalahan yang ada dengan menggunakan berbagai pendekatan, baik sains, teknologi, teknik, seni maupun matematika sehingga menjadi sebuah strategi untuk mempertahankan keberlangsungan hidup agar tetap mampu bertahan pada zaman yang serba cepat pada saat ini; 3) Penelitian Arsy, I., \& Syamsulrizal, S. Tahun 2021 dengan judul Pengaruh Pembelajaran Steam (Science, Technology, Engineering, Arts, and Mathematics) terhadap Kreativitas Peserta Didik, penelitian ini menggunakan metode telaah pustaka dari berbagai sumber. Sumber informasi tersebut dapat diperoleh melalui buku, jurnal, ebook, ataupun artikel ilmiah lainnya . hasil penelitian menunjukkan dengan menggunakan muatan STEAM memiliki pengaruh terhadap kreatifitas peserta didik; 4) Penelitian Siti Wahyuningsih, dkk. Tahun 2019 dengan judul Efek Metode STEAM pada Kreatifitas Anak Usia 5-6 Tahun, Metode dalam penelitian ini menggunakan penelitian eksperimen pretest dan post test dengan jumlah responden 25 anak. Hasil penelitian menunjukkan ada perbedaan kreativitas pada anak sebelum anak mendapatkan perlakuan dan sesudah anak mendapatkan perlakuan penerapan Metode STEAM. Metode STEAM dalam penerapannya menggunakan loosepart yang dapat meningkatkan kreatifitas anak.

Berdasarkan beberapa kajian pustaka di atas dapat disimpulkan analisis gap muatan STEAM merupakan hasil integrasi dari STEM dengan menambahkan A (Art) didalamnya, karena melalui pembelajaran STEAM anak akan memunculkan kreatifitas dan mampu memecahkan masalah sendiri.

Berdasarkan hasil wawancara pada observasi awal dengan guru dan kepala sekolah dibeberapa PAUD di Jawa Tengah bahwa melalui muatan STEAM anak akan belajar tanpa menyadari bahwa dirinya sedang belajar, karena muatan STEAM dikemas dalam bentuk permainan yang menyenangkan bagi anak, apalagi disaat pandemi seperti ini bagaimana memaknai efektifitas STEAM supaya anak dalam belajar dirumah tetap dapat memunculkan karakter kreatif dan kemandirian karena tanpa dampingan guru secara langsung, sehingga dengan menggunakan muatan STEAM diharapkan bisa efektif untuk membuat aktivitas orang tua bermain bersama anak dirumah, dan disituasi lainnya. Sehingga, diharapkan karakter kreatif dan kemandirian anak dapat berkembang.

Perlu adanya dukungan dan kerjasama yang baik antara pihak sekolah dengan orang tua dalam menyukseskan pembelajaran jarak jauh bermuatan STEAM seperti ketersedian media belajar yang digunakan anak saat belajar dirumah, hal tersebut telah diantisipasi dari pihak sekolah dengan upaya menyediakan bahan-bahan main yang bisa diambil orang tua di sekolah untuk mendukung kegiatan bermain menggunakan muatan STEAM selama pembelajaran jarak jauh dirumah, sehingga dengan upaya tersebut efektif dalam pembelajaran jarak jauh. Selain hal tersebut, dalam penilaian pembelajaran jarak jauh pihak sekolah juga meminta bantuan orang tua untuk menilai life skill anak ketika dirumah melalui google form yang dikirim pihak sekolah kepada orang tua. Selanjutnya, artikel ini menjelaskan pengaruh pembelajaran jarak jauh bermuatan STEAM terhadap karakter kreatif dan kemandirian anak usia 5-6 tahun di beberapa PAUD di Jawa Tengah, dengan meningkatkan kerjasama antara guru dan orang tua, sebagai mitra. 


\section{METODOLOGI}

Rancangan penelitian yang dipilih adalah penelitian deskriptif kuantitatif, menggambarkan keadaan subjek atau objek penelitian pada saat sekarang ini berdasarkan fakta-fakta yang tampak atau sebagaimana adanya. Menurut (Sugiyono, 2018) penelitian deskriptif kuantitatif adalah penelitian yang dilakukan untuk mengetahui keberadaan nilai variabel mandiri, baik satu variabel atau lebih (independen) tanpa membuat perbandingan atau menghubungkan dengan variabel lain dan permasalahan yang diteliti sudah jelas, tetap, realitas dianggap tunggal, teramati pola piker deduktif. Penelitian ini menggunakan metode survei dimana penulis menanyakan ke beberapa orang (responden) tentang data-data yang ingin penulis ketahui. Dengan menggunakan link google form. Tujuan utama penelitian ini untuk mengetahui pembelajaran jarak jauh bermuatan STEAM terhadap karakter kreatif dan kemandirian anak usis 5-6 tahun di beberapa PAUD di Jawa Tengah.

Populasi dari penelitian ini adalah seluruh guru dan orang tua di beberapa PAUD di Jawa Tengah. Pada penelitian ini populasi PAUD di Jawa Tengah $(n=140)$, dengan pengambilan sampel pada masing-masing kabupaten / kota di Jawa Tengah sejumlah 4 responden guru, 4 responden orang tua, dan 2 sampel PAUD tiap kabupaten / kota. Instrumen yang digunakan adalah angket pembelajaran bermuatan STEAM, angket karakter kreatif, dan angket kemandirian. Angket dibuat dengan menggunakan google form sehingga responden hanya mengisi angket yang disediakan secara online oleh peneliti. Melalui angket tersebut diharapkan respon responden dapat terlihat secara menyeluruh sehingga peneliti dapat melakukan analisa terkait pembelajaran jarak jauh bermuatan STEAM terhadap karakter kreatif dan kemandirian. Untuk lebih jelasnya langkah-langkah dalam pengumpulan data dapat dilihat pada gambar 1.

\begin{tabular}{|c|c|c|}
\hline Observasi Awal & & Koordinasi \\
\hline \multirow[t]{2}{*}{$\begin{array}{l}\text { Memberikan surat keterangan ijin } \\
\text { observasi dari pihak kampus yang } \\
\text { ditujukan kepada kepala sekolah yang } \\
\text { bersangkutan }\end{array}$} & & $\begin{array}{l}\text { Koordinasi dengan guru di daerah } \\
\text { menggunakan wahtsapp group dan meminta } \\
\text { kesediannya untuk membantu peneliti } \\
\text { dalam mencari data-data yang diperlukan }\end{array}$ \\
\hline & & $\downarrow$ \\
\hline Verifikasi Data & & Pengumpulan Data \\
\hline $\begin{array}{l}\text { Mengecek kembali data yang telah dicatat } \\
\text { dalam lembar instrumen, untuk berjaga- } \\
\text { jaga jika ada yang salah/keliru atau data } \\
\text { yang kurang }\end{array}$ & $\leftarrow$ & $\begin{array}{l}\text { Mencatat data sesuai dengan panduan } \\
\text { lembar instrumen yang telah dibuat } \\
\text { sebelumnya }\end{array}$ \\
\hline
\end{tabular}

\section{Gambar 1. Langkah-Langkah dalam Pengumpulan Data}

Teknik analisis yang digunakan dalam penelitian deskriptif kuantitatif ini menggunakan teknik observasi, wawancara, dokumentasi, dan angket. Kemudian dilakukan analisa oleh penulis untuk ditarik kesimpulan adapun langkah-langkah yang dilakukan dapat dilihat pada gambar 2.

Adapun kisi-kisi instrumen yang digunakan untuk mengumpulkan data dari variabel $(\mathrm{X})$ muatan STEAM terhadap variabel $\left(\mathrm{Y}_{1}\right.$ dan $\left.\mathrm{Y}_{2}\right)$ karakter kreatif dan kemandirian sebagai berikut : 1) Tabel 1. kisi-kisi instrumen muatan STEAM (lampiran), 2) Tabel 2. kisi-kisi instrumen karakter kreatif, 3) Tabel 3. kisi-kisi instrumen kemandirian. 


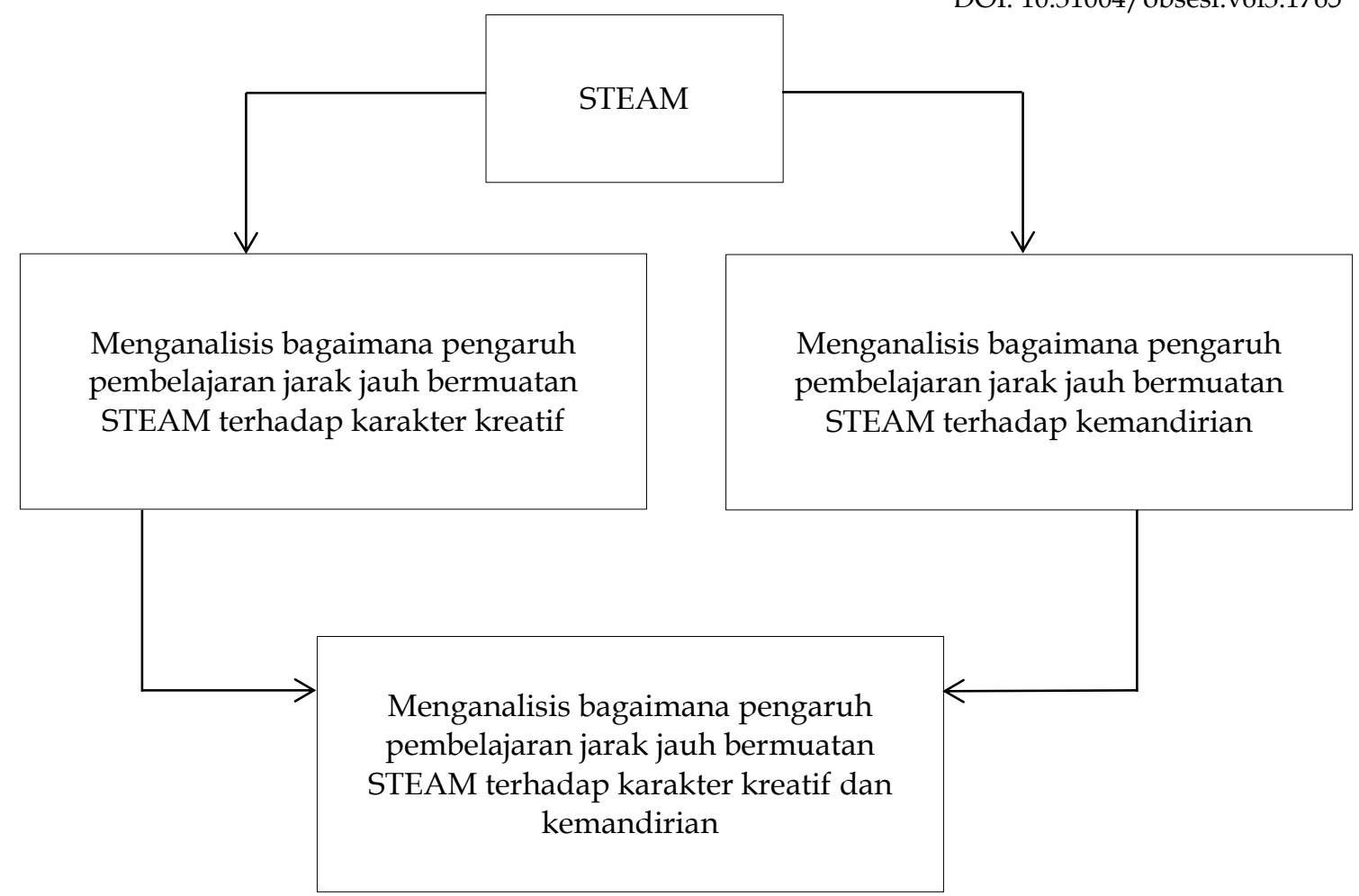

Gambar 2. Langkah-Langkah Analisa Pengaruh Pembelajaran Jarak Jauh Bermuatan STEAM Terhadap Karakter Kreatif dan Kemandirian

Tabel 2. Kisi-kisi Instrumen Karakter Kreatif

\begin{tabular}{|c|c|c|c|c|}
\hline Variabel & Indikator & Deskriptor & $\begin{array}{l}\text { Butir } \\
\text { Soal }\end{array}$ & Jumlah \\
\hline \multirow[t]{4}{*}{$\begin{array}{l}\text { Sikap } \\
\text { Kreatif }\end{array}$} & $\begin{array}{l}\text { Kelancaran } \\
\text { berpikir }\end{array}$ & $\begin{array}{l}\text { - Anak dapat menghasilkan banyak gagasan } \\
\text { atau jawaban atas sebuah persoalan } \\
\text { - Anak mampu menghasilkan sesuatu } \\
\text { - Anak dapat mengembangkan sesuatu } \\
\text { ide/gagasan berdasarkan gagasan yang sudah } \\
\text { ada }\end{array}$ & $\begin{array}{l}3,4 \\
5,6\end{array}$ & 6 \\
\hline & $\begin{array}{l}\text { Keluwesan } \\
\text { atau } \\
\text { fleksibilitas }\end{array}$ & $\begin{array}{l}\text { - Anak dapat melihat masalah dengan } \\
\text { menggunakan beberapa sudut pandang } \\
\text { - Anak dapat mengajukan beberapa pemecahan } \\
\text { masalah dengan pendekatan yang berbeda- } \\
\text { beda }\end{array}$ & $\begin{array}{l}7,8 \\
9,10\end{array}$ & 4 \\
\hline & Keaslian & $\begin{array}{l}\text { - Anak membuat hasil karya yang berbeda } \\
\text { dibandingkan teman-temannya dalam tema } \\
\text { yang sama } \\
\text { - Dalam hal bercerita, menjelaskan sesuatu, } \\
\text { menggambarkan atau memperagakan sesuatu, } \\
\text { anak menampilkan sesuatu yang berbeda } \\
\text { dibandingkan dengan teman-temannya }\end{array}$ & 13,14 & 4 \\
\hline & Elaborasi & $\begin{array}{l}\text { - Anak dapat menjelaskan dengan rinci } \\
\text { gagasannya } \\
\text { - Anak membuat hasil karya dengan teliti dan } \\
\text { terperinci } \\
\text { - Anak dapat membuat karangan cerita yang } \\
\text { kaya akan emosi dan penggambaran } \\
\text { lingkungan yang terperinci }\end{array}$ & $\begin{array}{l}15,16 \\
17,18 \\
19 \\
20,21\end{array}$ & 7 \\
\hline
\end{tabular}


Tabel 3. Kisi-kisi Instrumen Kemandirian

\begin{tabular}{|c|c|c|c|c|}
\hline \multirow{19}{*}{$\frac{\text { Variabel }}{\text { Kemandirian }}$} & Indikator & Diskriptor & Butir Soal & Jumlah \\
\hline & Kemampuan & - Anak dapat melakukan toilet training & 1,2 & 6 \\
\hline & Fisik & $\begin{array}{l}\text { - Anak dapat mengoperasikan alat bantu } \\
\text { makan sendiri }\end{array}$ & 3,4 & \\
\hline & & - Anak dapat menjaga kebersihan diri & 5,6 & \\
\hline & Percaya diri & $\begin{array}{l}\text { - Anak mampu menentukan pilihan dalam } \\
\text { mengolah kegiatan bermain Loosepart }\end{array}$ & 7,8 & 6 \\
\hline & & $\begin{array}{l}\text { - Anak berani mengemukakan pendapat } \\
\text { dalam sebuah masalah }\end{array}$ & 9,10 & \\
\hline & & $\begin{array}{l}\text { - Anak berani bertanya bila tidak } \\
\text { sependapat }\end{array}$ & 11,12 & \\
\hline & $\begin{array}{l}\text { Bertanggung } \\
\text { Jawab }\end{array}$ & $\begin{array}{l}\text { - Anak dapat menyelesaikan tugas yang } \\
\text { diberikan oleh guru }\end{array}$ & 13,14 & 2 \\
\hline & Disiplin & $\begin{array}{l}\text { - Anak tepat waktu dalam melaksanakan } \\
\text { tiap kegiatan anak }\end{array}$ & 15,16 & 4 \\
\hline & & $\begin{array}{l}\text { - Anak mampu mentaati dan menjalankan } \\
\text { peraturan main }\end{array}$ & 17,18 & \\
\hline & $\begin{array}{l}\text { Mudah } \\
\text { Bergaul }\end{array}$ & $\begin{array}{l}\text { - Anak memberi salam kepada orang yang } \\
\text { belum dikenal }\end{array}$ & 19,20 & 6 \\
\hline & & $\begin{array}{l}\text { - Anak dapat menghargai pendapat } \\
\text { temannya }\end{array}$ & 21,22 & \\
\hline & & $\begin{array}{l}\text { - Anak dapat berinteraksi dengan teman- } \\
\text { temannya }\end{array}$ & 23,24 & \\
\hline & $\begin{array}{l}\text { Saling } \\
\text { Berbagi }\end{array}$ & $\begin{array}{l}\text { - Anak senang berbagi makanan dan } \\
\text { minuman dengan temannya }\end{array}$ & 25,26 & 6 \\
\hline & & $\begin{array}{l}\text { - Anak senang berbagi mainan dengan } \\
\text { temannya }\end{array}$ & 27,28 & \\
\hline & & $\begin{array}{l}\text { - Anak mampu meminjamkan alat tulisnya } \\
\text { dengan temannya }\end{array}$ & 29,30 & \\
\hline & $\begin{array}{l}\text { Mengendalik } \\
\text { an Emosi }\end{array}$ & $\begin{array}{l}\text { - Anak tidak mengganggu temannya saat } \\
\text { kegiatan bermain Loosepart }\end{array}$ & 31,32 & 6 \\
\hline & & - Anak tidak teriak saat ditegur oleh guru & 33,34 & \\
\hline & & $\begin{array}{l}\text { - Anak tidak murung ketika bermain } \\
\text { Loosepart tidak selesai }\end{array}$ & 35,36 & \\
\hline
\end{tabular}

Dari hasil uji reliabilitas diperoleh data sebagaimana pada tabel 4.

Tabel 4. Hasil Uji Reliabilitas Instrumen

\begin{tabular}{lccc}
\hline \multicolumn{1}{c}{ Variabel } & Reliabilitas Coefficient & Cronbach Alpha & Keterangan \\
\hline STEAM & 10 item pertanyaan & 0.940 & Reliabel \\
Karakter Kreatif & 21 item pertanyaan & 0.915 & Reliabel \\
Kemandirian & 36 item pertanyaan & 0.917 & Reliabel \\
\hline
\end{tabular}

Sumber data : output SPSS yang diolah, 2021

Dari keterangan tabel di atas dapat diketahui bahwa masing-masing variabel memiliki Cronbach Alpha $>0,6$. Dengan demikian variabel (karakter kreatif, kemandirian, dan muatan STEAM) dapat dikatakan reliabel.

\section{HASIL DAN PEMBAHASAN}

Hasil analisis data menunjukkan bahwa adanya pengaruh antara pembelajaran jarak jauh bermuatan STEAM terhadap karakter kreatif dan kemandirian di beberapa PAUD di 
DOI: 10.31004/obsesi.v6i3.1765

Jawa Tengah. Namun hasil ini masih perlu pembahasan lebih lanjut untuk memberikan interprestasi yang lebih mendalam tentang hasil penelitian yang diperoleh dikaitkan dengan teori-teori maupun kerangka berfikir yang telah dikemukakan sebelumnya.

Berdasarkan survei penelitian di lapangan pembelajaran jarak jauh bermuatan STEAM dilakukan guru dengan upaya : 1) Guru mengajak anak untuk mengembangkan kemampuan berpikir tingkat tinggi dan memberikan kesempatan pada anak untuk melakukan pengamatan peristiwa yang dialami anak; 2) Ketersediaan berbagai media atau alat yang mampu mengembangkan bidang-bidang STEAM; 3) Guru mampu memprovokasi yang mendukung proses inkuiri pada anak, namun terkadang keluar tema; 4) Sudah terjadi kolaborasi antara guru dan anak dalam bereksplorasi dan bereksperimen untuk menghasilkan suatu karya; 5) Ketersediaan media pembelajaran yang memudahkan anak dalam memahami konsep matematika melalui aktivitas bermain seperti mengenal bentuk, jumlah, dan pola.

Hasil penelitian tersebut didukung dengan hasil penelitian sebelumnya seperti (Arsy \& Syamsulrizal, 2021) dan (Wahyuningsih et al., 2019), dengan hipotesis yang menyatakan bahwa muatan STEAM berpengaruh terhadap karakter kreatif dan kemandirian anak usia 56 tahun. Dampak dari penerapan model pembelajaran STEAM dalam kegiatan pembelajaran anak usia 5-6 tahun salah satunya berupa pengembangan sikap kreatif dan kemandirian anak, atau sebagai sarana untuk meningkatkan ketrampilan pemecahan masalah dalam kegiatan sehari-hari (Perignat \& Katz-Buonincontro, 2019).

STEAM merupakan akronim dari Science, Technology, Engineering, Arts, and Mathematics. Muatan STEAM memiliki dampak terhadap anak usia dini salah satunya yaitu meningkatkan minat anak dan pemahaman dalam teknologi dan kemampuan untuk memecahkan masalah di dunia nyata (Thuneberg et al., 2018). Seperti yang dijelaskan oleh (Hong, 2018) bahwa STEAM memuat pembelajaran berbasis teknologi ilmiah dan kemampuan dalam memecahkan masalah di dunia nyata.

Selain itu dengan model pembelajaran STEAM mendorong anak untuk mengembangkan rasa ingin tahu, keterbukaan pengalaman (Perignat \& Katz-Buonincontro, 2019) dan mengajukkan pertanyaan sehingga anak membangun pengetahuan disekitarnya dengan mengeksplorasi, mengamati, menemukan, dan menyelidiki sesuatu yang ada disekitarnya (Limbong et al., 2019). Fokus STEAM adalah pada menciptakan yaitu produk akhir dan proses pembuatan. Proses pembuatan lebih penting dibanding produk akhir karena di dalam prosesnya terdapat aspek eksplorasi, pemikiran kreatif, kemandirian, desain teknik, ekspresi kreatif, evaluasi, dan desain ulang (Perignat \& Katz-Buonincontro, 2019). Dalam proses tersebut, model STEAM dapat mengajarkan anak untuk berproses melalui kegiatan mengamati, bermain, mengenali pola, dan berlatih keterampilan berpikir kreatif serta keterampilan kerjasama dan komunikasi antar anak dalam menyelesaikan suatu tugas atau project yang diberikan oleh guru (Guyotte et al., 2014).

Berdasarkan perhitungan analisis data, diperoleh persentase terkait pembelajaran jarak jauh bermuatan STEAM terhadap karakter kreatif dan kemandirian sebagai berikut : a) Analisis profil pembelajaran bermuatan STEAM; b) Analisis pengaruh pembelajaran jarak jauh bermuatan STEAM terhadap karakter kreatif; c) Analisis pengaruh pembelajaran jarak jauh bermuatan STEAM terhadap kemandirian; d) Analisis pengaruh pembelajaran jarak jauh bermuatan STEAM terhadap karakter kreatif dan kemandirian.

Berdasarkan tabel 5., tentang profil pembelajaran bermuatan STEAM menggambarkan bahwa PAUD sudah mulai mengintegrasikan STEAM dalam pembelajaran, mayoritas dari responden menunjukkan $64 \%$ berada pada kategori tinggi. ditunjukkan dengan perolehan skor dari 140 responden diperoleh persentase dari analisis jawaban instrumen responden dengan kategori skor sangat tinggi $24 \%$, tinggi $64 \%$, cukup $12 \%$, rendah $0 \%$, dan sangat rendah $0 \%$, sehingga analisis deskriptif dari pembelajaran jarak jauh bermuatan STEAM menunjukkan hasil bahwa PAUD di Jawa Tengah sudah mulai mengintegrasikan STEAM dalam pembelajaran pada kategori tinggi dengan perolehan skor 89 dengan persentase $64 \%$ terletak pada interval $60-80$. 
Pengaruh Pembelajaran Jarak Jauh Bermuatan STEAM Terhadap Karakter Kreatif dan Kemandirian DOI: 10.31004 /obsesi.v6i3.1765

Tabel 5. Profil pembelajaran bermuatan STEAM

\begin{tabular}{ccccc}
\hline No. & Skor & Kategori & Frekuensi & Persentase $\%$ \\
\hline 1 & $80-100$ & sangat tinggi & 34 & $24 \%$ \\
2 & $60-80$ & tinggi & 89 & $64 \%$ \\
3 & $40-60$ & cukup & 17 & $12 \%$ \\
4 & $20-40$ & rendah & 0 & $0 \%$ \\
5 & $0-20$ & sangat rendah & 0 & $0 \%$ \\
\hline
\end{tabular}

Tabel 6. Gambar Output Uji Regresi (ANOVA) Antara Variabel STEAM (X) dengan Karakter Kreatif $\left(\mathrm{Y}_{1}\right)$

ANOVAa

\begin{tabular}{llrrrrr}
\hline Model & & Sum of Squares & \multicolumn{1}{c}{ df } & Mean Square & F & Sig. \\
\hline 1 & Regression & 5860.054 & 1 & 5860.054 & 125.851 & $.000^{\mathrm{b}}$ \\
& Residual & 6425.739 & 138 & 46.563 & & \\
& Total & 12285.793 & 139 & & & \\
& & & & & \\
\hline
\end{tabular}

a. Dependent Variable: karakter kreatif

b. Predictors: (Constant), steam

Berdasarkan tabel 6., diketahui F hitung sebesar 125.851 dengan taraf signifikan 0.000, oleh karena $\mathrm{p}<0,05$, maka model regresi dapat digunakan untuk memprediksi STEAM. Hal ini menunjukkan ada pengaruh STEAM terhadap karakter kreatif, sehingga hipotesis penelitian diterima.

Tabel 7. Gambar Output Uji Regresi (ANOVA) Antara Variabel STEAM (X) dengan Kemandirian $\left(\mathrm{Y}_{2}\right)$

ANOVAa

\begin{tabular}{llrrrrr}
\hline Model & & Sum of Squares & df & Mean Square & F & Sig. \\
\hline 1 & Regression & 36655.948 & 1 & 36655.948 & 78.082 & $.000^{\mathrm{b}}$ \\
& Residual & 64784.988 & 138 & 469.456 & & \\
& Total & 101440.936 & 139 & & & \\
\hline
\end{tabular}

a. Dependent Variable: kemandirian

b. Predictors: (Constant), steam

Berdasarkan tabel 7., diketahui F hitung sebesar 78.082 dengan taraf signifikan 0.000, oleh karena $\mathrm{p}<0.05$, maka model regresi dapat digunakan untuk memprediksi STEAM. Hal ini menunjukkan ada pengaruh STEAM terhadap kemandirian, sehingga hipotesis penelitian diterima.

Tabel 8. Teknik Analisis Data Variabel STEAM (X) Terhadap Karakter Kreatif ( $\mathrm{Y}_{1)}$ dan Kemandirian $\left(\mathrm{Y}_{2}\right)$ Correlations

\begin{tabular}{llrr}
\hline & & karakter kreatif & kemandirian \\
\hline Karakter kreatif & Pearson Correlation & 1 & $-.420^{* *}$ \\
& Sig. (2-tailed) & & .000 \\
& $\mathrm{~N}$ & 140 & 140 \\
Kemandirian & Pearson Correlation & $-.420^{* *}$ & 1 \\
& Sig. (2-tailed) & .000 & 140 \\
\hline
\end{tabular}

${ }^{* *}$ Correlation is significant at the 0.01 level (2-tailed)

Berdasarkan tabel 8., diketahui bahwa karakter kreatif dan kemandirian memiliki hubungan dengan nilai signifikansi $0.000(<0.05)$ dan nilai person $0.420\left(>0.138 r_{\text {tabel }}\right)$. Berdasarkan kesimpulan pada tabel 5-8, uji hipotesis dengan menggunakan SPSS diperoleh 
DOI: 10.31004/obsesi.v6i3.1765

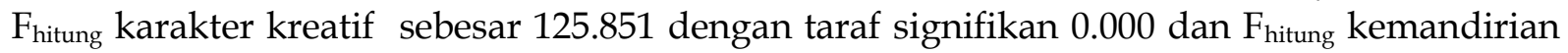
sebesar 78.082 dengan taraf signifikan 0.000 oleh karena $p<0.05$, maka model regresi dapat digunakan untuk memprediksi muatan STEAM terhadap karakter kreatif dan STEAM terhadap kemandirian. Hal ini menunjukkan bahwa hipotesis diterima dan ada pengaruh antara muatan STEAM terhadap karakter kreatif dan muatan STEAM terhadap kemandirian. Sedangkan berdasarkan teknik analisis data diketahui bahwa karakter kreatif dan kemandirian memiliki hubungan dengan nilai signifikansi $0.000(<0.05)$ dan nilai person 0.420 $\left(>0.138 r_{\text {tabel }}\right)$.

Penelitian ini banyak ditemukan kendala diantaranya banyak orang tua yang belum memahami tugas perkembangan anak dan proses pembelajaran anak saat pembelajaran jarak jauh, maka artikel ini berusaha menjelaskan pentingnya penguatan pembelajaran jarak jauh bermuatan STEAM pada anak agar anak memiliki pengalaman belajar yang efektif terutama dalam meningkatkan karakter kreatif dan kemandirian. Selain itu, proses pembelajaran yang berlangsung secara online menyebabkan anak cepat bosan dan tidak bisa selalu fokus dengan layar laptop. Kendala lain, guru tidak bisa menilai kinerja anak secara langsung sehingga memperbantukan orang tua untuk menilai life skill anak ketika dirumah melalui google form yang dikirim pihak sekolah kepada orang tua. Dengan meningkatkan kerjasama antara guru dan orang tua diharapkan kendala-kendala tersebut dapat teratasi.

\section{Pembahasan}

Berdasarkan hasil penelitian ini dikemukakan dan dibahas temuan penelitian yang menunjukkan bahwa terdapat pengaruh pembelajaran jarak jauh bermuatan STEAM terhadap karakter kreatif dan kemandirian anak usia 5-6 tahun dibeberapa PAUD di Jawa Tengah. Keterbaruan STEAM yang merupakan integrasi dari STEM dengan penambahan unsur seni $(A r t)$ berpengaruh terhadap karakter kreatif dan kemandirian anak, karena melalui pembelajaran STEAM anak akan memunculkan kreatifitas dan mampu memecahkan masalah sendiri.

Didukung oleh hasil penelitian yang relevan sebelumnya, menyatakan bahwa : "STEAM berkembang dari STEM dengan penambahan unsur "Art" didalamnya. Unsur seni atau "Art" berkontribusi terhadap: 1) kemampuan berpikir yang meliputi kegiatan menalar, intuisi, persepsi, imajinasi, kreativitas, problem solving; 2) kemampuan sosial yang meliputi kepercayaan diri, pengendalian diri, resolusi konflik, kolaborasi, empati dan toleransi; 3) motivasi untuk belajar dengan indikasi keterlibatan aktif, perhatian lebih, persisten dan berani mengambil resiko, hal ini tentu saja menjadikan STEAM sebagai salah satu pendekatan terkini yang dapat diterapkan dalam Pendidikan Anak Usia Dini (Putri \& Taqiudin, 2021)". Senada dengan pendapat tersebut upaya peningkatan karakter kreatif dan kemandirian dimasa pandemi ini salah satunya dengan cara pembiasaan agar tetap mengasah sikap kreatif dan kemandirian pada anak, salah satu pembiasaan dalam meningkatkan karakter kreatif dan kemandirian dapat dimunculkan dengan menyisipkan pembelajaran bermuatan STEAM dalam kehidupan sehari-hari anak, peran serta dukungan orang tua dan lingkungan saat pembelajaran jarak jauh mempunyai pengaruh besar terhadap perkembangan anak, sehingga STEAM tetap konsisten diterapkan selama pembelajaran jarak jauh, karena melalui pembelajaran bermuatan STEAM inilah tidak menutup kemungkinan dapat menggali karakter kreatif dan kemandirian anak melalui kemampuan dalam memunculkan solusi dan ide baru untuk memecahkan masalah. Untuk dapat mendukung pemahaman tersebut, maka orang tua harus memberikan stimulasi yang tepat berlandaskan pada konsep pendidikan anak usia dini (Sari \& Rahma, 2019)"

"Menurut Arsy \& Syamsulrizalv (2021) STEAM merupakan sarana bagi peserta didik untuk menciptakan ide/gagasan berbasis sains dan teknologi melalui kegiatan berpikir dan bereksplorasi dalam memecahkan masalah berdasarkan pada lima disiplin ilmu yang terintegrasi. Pemecahan masalah jika dilakukan berdasarkan beberapa disiplin ilmu, maka akan menghasilkan sebuah solusi yang sangat tepat, tidak hanya pemecahan masalah 
DOI: 10.31004/obsesi.v6i3.1765

matematik namun berdasarkan konsep yang berhubungan dengan disipilin ilmu lain sehingga pemecahan masalah akan menjadi sangat menarik, efektif dan efisien"

Hal ini senada dengan penelitian (Wahyuningsih et al., 2019) menjelaskan bahwa pembelajaran berbasis Science, Technology, Engineering, Art, And Mathematics (STEAM) dapat mengembangkan kreativitas anak serta menerapkan model pembelajaran aktif dan kreatif, dimana anak berperan aktif dalam menggali informasi mengenai hal-hal baru dalam diri anak melalui lingkungan sekitar.

Berdasarkan uraian di atas maka analisis keterbaruan pada penelitian ini yaitu bagaimana supaya pembelajaran jarak jauh dimasa pandemi covid-19 dapat mengintegrasikan karakter kreatif dan kemandirian anak. Berdasarkan hal tersebut, peneliti telah melakukan penelitian dengan menerapkan muatan STEAM saat pembelajaran jarak jauh. Hal tersebut untuk mengungkap pengaruh pembelajaran jarak jauh bermuatan STEAM terhadap karakter kreatif dan kemandirian anak usia 5 - 6 tahun dibeberapa PAUD di Jawa Tengah, dengan penerapan pembelajaran jarak jauh menggunakan muatan STEAM maka karakter kreatif dan kemandirian anak dapat terintegrasi.

\section{SIMPULAN}

Pembelajaran jarak jauh bermuatan STEAM terbukti berpengaruh terhadap karakter kreatif dan kemandirian anak usia 5-6 tahun dibeberapa PAUD di Jawa Tengah. Kondisi pandemi memang mengubah hampir seluruh sektor kegiatan, termasuk pendidikan. Pembelajaran yang semula tatap muka kini menjadi pembelajaran daring. Masing-masing sekolah tentu memiliki kebijakannya tersendiri, namun penggunaan pembelajaran bermuatan STEAM bisa menjadi langkah yang efektif dalam pembelajaran jarak jauh terutama dalam meningkatkan karakter kreatif dan kemandirian. Selain itu, akronim sains, teknologi, teknik, seni, dan matematika yang disingkat dengan STEAM menjadikan anak untuk lebih mampu dalam memecahkan persoalan-persoalan yang dihadapi dalam kehidupan sehari-hari menjadi lebih efektif dan kreatif.

\section{UCAPAN TERIMA KASIH}

Ucapan terima kasih kepada orang tua, suami, dan anak yang telah memberikan dukungan materi dan motivasi serta memberikan izin penelitian kepada saya, sehingga penelitian ini dapat berjalan dengan baik dan dalam keaadaan sehat. Terimakasih juga, saya ucapkan kepada pihak-pihak terkait yaitu Bapak/Ibu guru dan wali murid anak usia 5-6 tahun dibeberapa PAUD di Jawa Tengah yang telah membantu penelitian saya secara tidak langsung.

\section{DAFTAR PUSTAKA}

Adiwijaya. (2020). Bergesernya pola konsumsi masyarakat sebagai dampak dari mewabahnya virus corona. Journal Sosiologi, III(2), 46-54.

Arsy, I., \& Syamsulrizal, S. (2021). Pengaruh Pembelajaran Steam (Science, Technology, Engineering, Arts, and Mathematics) Terhadap Kreativitas Peserta Didik. Biolearning Journal, 8(1), 24-26. https:/ / doi.org/10.36232/jurnalbiolearning.v8i1.1019

Becker, K., \& Park, K. (2011). Effects of integrative approaches among science, technology, engineering, and mathematics (STEM) subjects on students' learning: A preliminary. Journal of STEM Education, 12(5), 23-38.

Force. (2014). Innovate A Blueprint for Science, Technology, Engineering, and Mathematics in California Public Education. In Californians Dedicated to Education Foundation (Issue May). http://www.cde.ca.gov/pd/ca/sc/documents/innovate.pdf

Goldschmidt, K. (2020). The COVID-19 Pandemic: Technology use to Support the Wellbeing of Children. Journal of Pediatric Nursing, 53, 88-90. https://doi.org/10.1016/j.pedn.2020.04.013 
Gunawan, P., Ernawati, A., Hasnawati, Amrullah, F., \& Asmar, S. (2020). Model Pembelajaran Steam ( Science, Technology, Engineering, Art, Mathematics ) Dengan Pendekatan Saintifik. Buku, 1-64.

Guyotte, K. W., Sochacka, N. W., Costantino, T. E., \& Walther, J. (2014). Steam as Social Practice: Cultivating Creativity in Transdisciplinary Spaces. Art Education, 67(6), $12-$ 19. https:// doi.org/10.1080/00043125.2014.11519293

Henriksen, D. (2017). Creating STEAM with Design Thinking: Beyond STEM and Arts Integration. Steam, 3(1), 1-11. https://doi.org/10.5642/steam.20170301.11

Henriksen, Danah. (2014). Full STEAM Ahead: Creativity in Excellent STEM Teaching Practices. Steam, 1(2), 1-9. https://doi.org/10.5642/steam.20140102.15

Herro, D., \& Quigley, C. (2016). Innovating with STEAM in middle school classrooms: remixing education. On the Horizon, 24(3), 190-204. https:// doi.org/10.1108/OTH-032016-0008

Hong. (2018). STEAM Education in Korea: Current Policies and Future Directions Policy Trajectories and Initiatives in STEM Education STEAM Education in Korea : Current Policies and Future Directions. December 2017.

Kang, N.-H. (2019). A review of the effect of integrated STEM or STEAM (science, technology, engineering, arts, and mathematics) education in South Korea. Asia-Pacific Science Education, 5(1), 6. https:// doi.org/10.1186/s41029-019-0034-y

Kelley, T. R., \& Knowles, J. G. (2016). A conceptual framework for integrated STEM education. International Journal of STEM Education, 3(1), 3-11. https:// doi.org/10.1186/s40594016-0046-Z

Limbong, I., Munawar, M., \& Kusumaningtyas, N. (2019). Perencanaan pembelajaran paud berbasis steam ( science, technology, eingeneering, art, mathematic ). In Seminar Nasional PAUD 2019 (pp. 203-212). http://conference.upgris.ac.id/index.php/Snpaud2019/article/view/450

Margot, K. C., \& Kettler, T. (2019). Teachers' perception of STEM integration and education: a systematic literature review. International Journal of STEM Education, 6(1). https:// doi.org/10.1186/s40594-018-0151-2

Martinis. (2013). Panduan Pendidikan Anak Usia Dini. GP Press.

Mulyani, T. (2019). Pendekatan Pembelajaran STEM untuk menghadapi Revolusi. Seminar Nasional Pascasarjana 2019, 453-460.

Munandar, S. C. U. (2009). Pengembangan Kreativitas Anak Berbakat. Rineka Cipta.

Perignat, E., \& Katz-Buonincontro, J. (2019). STEAM in practice and research: An integrative literature review. Thinking Skills and Creativity, 31, 31-43. https:// doi.org/10.1016/j.tsc.2018.10.002

Purwanto, A. (2020). Terhadap Proses Pembelajaran Online di Sekolah Dasar. Edupsycouns Journal, 2(1), 1-12.

Putri, S. U., \& Taqiudin, A. A. (2021). Steam-PBL: Strategi Pengembangan Kemampuan Memecahkan Masalah Anak Usia Dini. Jurnal Obsesi : Jurnal Pendidikan Anak Usia Dini, 6(2), 856-867. https:// doi.org/10.31004/obsesi.v6i2.1270

Sari, D. Y., \& Rahma, A. (2019). Meningkatkan Pemahaman Orang Tua dalam Menstimulasi Perkembangan Anak dengan Pendekatan Steam melalui Program Home Visit. Tunas Siliwangi: Jurnal Program Studi Pendidikan Guru PAUD STKIP Siliwangi Bandung, 5(2), 93-105.

Subramaniam, M. M., Ahn, J., Fleischmann, K. R., \& Druin, A. (2012). Reimagining the Role of School Libraries in STEM Education: Creating Hybrid Spaces for Exploration Author ( s ): Mega M . Subramaniam, June Ahn, Kenneth R. Fleischmann, Allison Druin Reviewed work ( s ): Source: The Library Quarterly, Vol . 82 , No. 82(2), 161-182. https:// doi.org/10.1086/664578

Sugiyono. (2018). Metode Penelitian Kuantitatif. Alfabeta.

Sutarto, J., Education, N., Education, F., \& Semarang, U. N. (2021). Determining Factors That Affect the Quality of Process and Training Results of Non-formal PAUD Educators in 
Indonesia.

İlköğretim

https://doi.org/10.17051/ilkonline.2021.02.22

Thuneberg, H. M., Salmi, H. S., \& Bogner, F. X. (2018). How creativity, autonomy and visual reasoning contribute to cognitive learning in a STEAM hands-on inquiry-based math

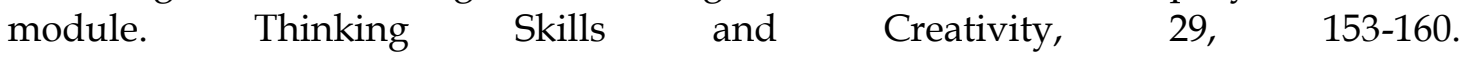
https://doi.org/10.1016/j.tsc.2018.07.003

Wahyuningsih, S., Pudyaningtyas, A. R., Hafidah, R., Syamsuddin, M. M., Nurjanah, N. E., \& Rasmani, U. E. E. (2019). Efek Metode STEAM pada Kreatifitas Anak Usia 5-6 Tahun. Jurnal Obsesi: Jurnal Pendidikan Anak Usia Dini, 4(1), 305. https://doi.org/10.31004/obsesi.v4i1.305

Wilder-Smith, A., \& Freedman, D. O. (2020). Isolation, quarantine, social distancing and community containment: Pivotal role for old-style public health measures in the novel coronavirus (2019-nCoV) outbreak. Journal of Travel Medicine, 27(2), 1-4. https://doi.org/10.1093/jtm/taaa020

Yakman, G., \& Lee, H. (2012). Exploring the Exemplary STEAM Education in the U.S. as a Practical Educational Framework for Korea. Journal of The Korean Association For Science Education, 32(6), 1072-1086. https:/ / doi.org/10.14697/jkase.2012.32.6.1072 


\section{Lampiran}

Tabel 1. Kisi-kisi Instrumen Muatan STEAM

\begin{tabular}{|c|c|c|c|c|}
\hline No. & Aspek & Indikator & Favourable & Unfavourable \\
\hline 1. & Science & $\begin{array}{l}\text { Aspek science pada pembelajaran bermuatan } \\
\text { STEAM memungkinkan anak untuk } \\
\text { menemukan sesuatu, mengamati, } \\
\text { mengidentifikasi, tentang perubahan- } \\
\text { perubahan yang terjadi dan bagaimana } \\
\text { mereka berpartisipasi dan berkontribusi } \\
\text { dalam kegiatan-kegiatan menjaga lingkungan } \\
\text { sekitar. }\end{array}$ & $\begin{array}{l}\text { Guru menyediakan media pembelajaran yang } \\
\text { memungkinkan anak melakukan pengamatan, } \\
\text { berpikir, dan mengaitkan antar konsep } \\
\text { atau peristiwa yang dialami anak. } \\
\text { Contoh : pertumbuhan atau perubahan biji menjadi } \\
\text { tanaman }\end{array}$ & $\begin{array}{lrr}\text { Guru menyediakan } & \text { media } \\
\text { pembelajaran } \quad \text { yang } & \text { tidak } \\
\text { memungkinkan anak melakukan } \\
\text { pengamatan, berpikir, dan mengaitkan } \\
\text { antar } & \text { konsep } \\
\text { atau peristiwa yang dialami anak. }\end{array}$ \\
\hline 2. & Technology & $\begin{array}{l}\text { Aspek technology pada pembelajaran } \\
\text { bermuatan STEAM mendorong anak agar } \\
\text { dapat memiliki kemampuan menggunakan } \\
\text { dan mengembangkannya berdasarkan } \\
\text { kebutuhan, minat dan idenya sendiri melalui } \\
\text { alat dan bahan yang telah disiapkan. }\end{array}$ & $\begin{array}{l}\text { Guru menyediakan media pembelajaran yang dapat } \\
\text { mendorong anak dalam memilih alat yang digunakan } \\
\text { untuk menyelesaikan pekerjaan. } \\
\text { Contoh : sekop kecil, kapas, air, tanah, gelas, botol }\end{array}$ & $\begin{array}{l}\text { Guru menyediakan media } \\
\text { pembelajaran yang tidak dapat } \\
\text { mendorong anak dalam memilih alat } \\
\text { yang digunakan untuk menyelesaikan } \\
\text { pekerjaan. }\end{array}$ \\
\hline 3. & Engineering & $\begin{array}{l}\text { Aspek engineering pada pembelajaran } \\
\text { bermuatan STEAM memudahkan anak dalam } \\
\text { menyusun atau merangkai menjadi sebuah } \\
\text { bentuk atau bentuk lainnya. }\end{array}$ & $\begin{array}{l}\text { Guru menyediakan media pembelajaran yang } \\
\text { memudahkan anak dalam menggunakan alat atau } \\
\text { benda untuk merangkai sesuatu. } \\
\text { Contoh : proses menanam kecambah }\end{array}$ & $\begin{array}{l}\text { Guru menyediakan media } \\
\text { pembelajaran yang tidak memudahkan } \\
\text { anak dalam menggunakan alat atau } \\
\text { benda untuk merangkai sesuatu. }\end{array}$ \\
\hline 4. & Art & $\begin{array}{l}\text { Aspek art pada pembelajaran bermuatan } \\
\text { STEAM memungkinkan anak dalam } \\
\text { menciptakan kebebasan dalam bereksplorasi } \\
\text { dan berksperimen untuk menghasilkan suatu } \\
\text { karya. }\end{array}$ & $\begin{array}{l}\text { Guru menyediakan media pembelajaran yang } \\
\text { memungkinkan anak menciptakan sesuatu yang } \\
\text { menarik sehingga dapat memberikan kesenangan. } \\
\text { Contoh : menggambar tanaman, kolase }\end{array}$ & $\begin{array}{l}\text { Guru menyediakan } r \text { media } \\
\text { pembelajaran yang tidak } \\
\text { memungkinkan anak menciptakan } \\
\text { sesuatu yang menarik sehingga tidak } \\
\text { dapat memberikan kesenangan. }\end{array}$ \\
\hline 5. & Mathematic & $\begin{array}{l}\text { Aspek mathematic pada pembelajaran } \\
\text { bermuatan STEAM mengenalkan konsep } \\
\text { matematika melalui aktivitas bermain seperti } \\
\text { mengenal besaran (berapa banyak atau } \\
\text { berapa jumlah), struktur (bentuk), ruang } \\
\text { (sudut dan jarak), pola, bilangan, dan lain } \\
\text { sebagainya. }\end{array}$ & $\begin{array}{l}\text { Guru menyediakan media pembelajaran yang } \\
\text { memudahkan anak dalam memahami konsep } \\
\text { matematika melalui aktivitas bermain seperti } \\
\text { mengenal jumlah, bentuk, dan pola. } \\
\text { Contoh : menghitung biji kacang ijo yang ditanam, } \\
\text { menghitung biji yang tumbuh, mengukur panjang } \\
\text { kecambah, menyebutkan bentuk biji dan daun }\end{array}$ & $\begin{array}{l}\text { Guru menyediakan media } \\
\text { pembelajaran yang tidak memudahkan } \\
\text { anak dalam memahami konsep } \\
\text { matematika melalui aktivitas bermain } \\
\text { seperti mengenal jumlah, bentuk, dan } \\
\text { pola. }\end{array}$ \\
\hline
\end{tabular}

(Force, 2014) 